\title{
Population genetic structure of two herds of Aberdeen Angus cattle breed in Colombia
}

\author{
Estructura genética poblacional de dos hatos de ganado bovino Aberdeen Angus en Colombia \\ Estrutura genética da população de dois rebanhos da raça Aberdeen Angus na Colômbia
}

Alejandra M Moreno-Sierra ${ }^{2 *}$ (D); Mario F Cerón-Muñoz ${ }^{2}$ (D); Iván D Soto-Calderón ${ }^{1 *}$ (iD).

\begin{abstract}
${ }^{1}$ Laboratorio de Genética Animal, Grupo de Investigación en Agrociencias, Biodiversidad y Territorio (GAMMA), Instituto de Biología, Facultad de Ciencias Exactas y Naturales, Universidad de Antioquia.

${ }^{2}$ Grupo de Investigación en Agrociencias, Biodiversidad y Territorio (GAMMA), Facultad de Ciencias Agrarias, Universidad de Antioquia.
\end{abstract}

To cite this article:

Moreno-Sierra AM, Cerón-Muñoz MF, Soto-Calderon I. Population genetic structure of two herds of Aberdeen Angus cattle breed in Colombia. Rev Colomb Cienc Pecu 2021; 34(4): 278-290. DOI: https://doi.org/10.17533/udea.rccp.v34n4a05

\section{Abstract}

Background: Two biotypes of Aberdeen Angus cattle breed, known as Old Type and New Type, that differ in their origin and beef production are formally recognized. In Colombia, this breed has been commercialized for approximately 80 years. Studies on the origin, kinship and levels of genetic diversity of this breed in Colombian herds are scarce, yet important for planning crossing and management strategies. Objective: To measure the genetic diversity and structure of two Colombian herds of Old Type and New Type biotypes of Aberdeen Angus from Huila and Cundinamarca provinces and assess mitochondrial introgression with other breeds. Methods: A set of ten microsatellites and sequences of the Mitochondrial Control Region were characterized. Estimators of genetic diversity and population differentiation along with tests of population assignment were applied. Results: Nuclear loci were highly polymorphic as shown by the Polymorphic Information Content (0.599) and the Probability of Identity $\left(1.89610^{-08}\right)$. Both populations were highly diverse and clearly differentiated into two groups corresponding to the Old Type and New Type phenotypes. In contrast, mitochondrial data failed to distinguish these two groups and showed extensive admixture. Conclusions: This study optimized a set of ten highly polymorphic nuclear markers that may be used for parentage and population genetic studies of Aberdeen Angus. Genetic differentiation in these loci agreed with phenotypic differences of the Old and New Types. However, mitochondrial data indicated ancestry of multiple European breeds in the origin of Colombian Aberdeen Angus.

Keywords: Aberdeen Angus; bovine; biotype; beef cattle; cattle; cattle breed; genetic diversity; genetic structure; kinship; microsatellites; mitochondrial DNA; mitochondrial introgression; phenotype; polymorphic markers; population genetics.

Received: December 9, 2019; accepted: October 16, 2020

*Corresponding author. Calle 70 No. 52-21, Medellín, Colombia. Tel.: +573137091801. E-mail: ivan.soto@udea.edu.co 


\section{Resumen}

Antecedentes: Dentro de la raza Aberdeen Angus existen dos biotipos conocidos como Old Type y New Type, las cuales difieren en su origen y producción de carne. En Colombia, esta raza se ha venido comercializando desde hace aproximadamente 80 años. No obstante, aún no se han realizado estudios sobre su origen, parentesco y niveles de diversidad genética de esta raza en hatos colombianos, lo cual es importante para planear estrategias de cruce y manejo. Objetivo: Medir la diversidad y estructura genética de dos hatos colombianos de Aberdeen Angus Old Type y New Type de Huila y Cundinamarca y evaluar la introgresión mitocondrial con otras razas. Métodos: Se caracterizó un grupo de diez loci microsatélite y se secuenció la Región Control Mitocondrial. Se aplicaron estimadores de diversidad genética y diferenciación poblacional, junto con pruebas de asignación poblacional. Resultados: Los loci microsatélite fueron altamente polimórficos, tal como lo indicaron el Contenido de Información Polimórfica $(0,599)$ y la Probabilidad de Identidad $\left(1,89610^{-08}\right)$. Las poblaciones evaluadas de Aberdeen Angus en Colombia fueron altamente diversas y se diferenciaron claramente en dos grupos correspondientes a los fenotipos Old Type y New Type. En contraste, los datos mitocondriales no recobraron estos dos grupos y mostraron una amplia mezcla genética. Conclusiones: Este estudio optimizó un grupo de diez marcadores altamente polimórficos que pueden ser usados para estudios de parentesco y genética poblacional de Aberdeen Angus. La diferenciación genética en loci nucleares concordó con las diferencias fenotípicas entre Old y New Types, pero los datos mitocondriales indicaron ancestría de múltiples razas europeas en el origen del Aberdeen Angus colombiano.

Palabras clave: Aberdeen Angus; ADN mitocondrial; bovino; biotipo; diversidad genética; estructura genética; fenotipo; ganado; ganado de carne; genética de poblaciones; introgresión mitocondrial; marcadores polimórficos; microsatélites; parentesco; raza de ganado.

\section{Resumo}

Antecedentes: Dentro da raça Aberdeen Angus há dois biótipos conhecidos como Old Type e New Type, que diferem em sua origem e produção de carne. Na Colômbia, esta raça é comercializada há aproximadamente 80 anos. Entretanto, estudos sobre a origem, o parentesco e os níveis de diversidade genética desta raça em rebanhos colombianos ainda não foram realizados, o que é importante para o planejamento de cruzamentos e estratégias de manejo. Objetivo: Medir a diversidade genética e a estrutura de dois rebanhos colombianos de biótipos de Old Type e New Type de Aberdeen Angus de Huila e Cundinamarca e avaliar a introgressão mitocondrial com outras raças. Métodos: Um grupo de dez loci de microssatélites foi caracterizado e a Região de Controle Mitocondrial foi sequenciada. As estimativas de diversidade genética e diferenciação populacional foram aplicadas, juntamente com testes de designação populacional. Resultados: Os locus microssatélites foram altamente polimórficos, conforme indicado pelo Conteúdo de Infomação Polimórfica $(0,599)$ e Probabilidade de Identidade $\left(1,89610^{-08}\right)$. As populações avaliadas de Aberden Angus na Colômbia eram altamente diversificadas e claramente diferenciadas em dois grupos correspondentes aos fenótipos do Old Type e New Type. Em contraste, os dados mitocondriais não recuperaram esses dois grupos e mostraram um amplo mix genético. Conclusões: Este estudo otimizou um grupo de dez marcadores altamente polimórficos que podem ser usados para estudos genéticos de parentesco e população de Aberdeen Angus. A diferenciação genética nos loci nucleares concordou com as diferenças fenotípicas entre os Old e New Types, mas os dados mitocondriais indicam ancestralidade de várias raças européias na origem do Aberdeen Angus colombiano.

Palavras-chave: Aberdeen Angus; ADN mitocondrial; biótipo; diversidade genética; estrutura genética; gado; gado de corte; bovino; fenótipo; genética populacional; introgressão mitocondrial; marcadores polimórficos; microssatélites; parentesco; raça de gado. 


\section{Introduction}

Reduction in genetic variation is expected in commercial cattle as a consequence of artificial selection and domestication, which may raise levels of inbreeding and lead to fixation of deleterious alleles (Taberlet et al., 2008). Furthermore, artificial insemination has increased the risk of extinction of certain cattle breeds by increasing the selective pressure and the rate of genetic change, with a concomitant reduction in effective population sizes (Taberlet et al., 2008). This highlights the importance of recognizing population genetic units and formulating strategies to preserve the genetic diversity of domestic breeds as means for their conservation, facilitate their potential to respond to biotic and abiotic challenges and ultimately guarantee their long-term productivity.

Aberdeen Angus is a cattle breed of the utmost importance in the beef market. This breed is original from Scotland and it is known for its small size, short head-tail distance, fat deposit and hardiness (Villegas Castagnasso et al., 2015). Unlike the traditional Scottish phenotype called Old Type, a more recent variety called New Type was shaped in the 1960's and 1970's in Canada and USA, which are of a large size, more muscular, and exhibits more cylindric body and leaner carcasses than the Old Type (Asociación Argentina de Angus, 2014).

The earliest records of Aberdeen Angus in Colombia date back to the late $19^{\text {th }}$ century, when around 100 individuals of Old Type were introduced from Scotland into Huila and Caquetá provinces. These historical population correspond to the founders of herds in Tierraleja and Tamalá (Cundinamarca and Huila, respectively). More recently, new collections of Aberdeen Angus New Type were also introduced from North America (Piñeros, 1980).

Anecdotical records from livestock breeders and retailers indicate that Aberdeen Angus have been historically crossed with Colombian breeds and other European breeds such as Normande to improve its performance and productivity
(Bedoya et al., 2001). Outbreeding in Aberdeen Angus is no longer a common practice and it is thought to have ceased completely in more recent years (Piñeros, 1980). Current efforts in regions with a tradition of Aberdeen Angus breeding such as the Colombian provinces of Antioquia, Cundinamarca and Huila are aimed at rescuing this breed through crosses with New Type specimens, to the point that Aberdeen Angus herds in Colombia are perceived as relatively pure (Piñeros, 1980). A previous analysis of Aberdeen Angus in Antioquia with ten microsatellite loci evidenced high genetic diversity as compared to other local breeds (Montoya etal.,2010). However,implementation of population genetic studies in other Colombian regions with a breeding tradition of Aberdeen Angus is an important step to assess the extent of admixture and relatedness with other breeds, and design management plans for this breed. Given the limited knowledge regarding the origin and introgression of Aberdeen Angus in Colombia, this study aimed to measure the levels of both nuclear and mitochondrial genetic diversity, the differentiation of Old Type and New Type herds of Aberdeen Angus in Huila and Cundinamarca and assess mitochondrial introgression with other breeds.

\section{Materials and Methods}

\section{Population sample}

A total of 29 plucked hair samples were provided by the animal owners of "Tamalá" (Algeciras, Huila) and "Tierraleja" (La Calera, Cundinamarca) herds. Ten-generation genealogical records were used to select the least related individuals within each herd and these individuals were split into two groups according to their Old Type and New Type ancestry (Osorio and Toro 2018). The groups consisted of 14 individuals with the highest levels of Old Type (>50\%) named Old Type Colombia (OTC), and 15 100\% New Type named New Type Colombia (NTC). 
Table 1. List of 29 individuals of Old Type Colombia (OTC) and New Type Colombia (NTC) included in this study and their corresponding ancestries (Osorio and Toro 2018).

\begin{tabular}{cccccc}
\hline & Old Type Colombia & & \multicolumn{3}{c}{ New Type Colombia } \\
\hline ID & \% New Type & \% Old Type & ID & \% New Type & \% Old Type \\
\hline 296 & 25.0 & 75.0 & 246 & 100 & 0 \\
232 & 25.0 & 75.0 & 244 & 100 & 0 \\
284 & 25.0 & 75.0 & 210 & 100 & 0 \\
334 & 12.5 & 87.5 & 214 & 100 & 0 \\
327 & 25.0 & 75.0 & 222 & 100 & 0 \\
350 & 25.0 & 75.0 & 242 & 100 & 0 \\
396 & 25.0 & 75.0 & 252 & 100 & 0 \\
417 & 25.0 & 75.0 & $230 C$ & 100 & 0 \\
401 & 25.0 & 75.0 & 236 & 100 & 0 \\
380 & 12.5 & 87.5 & 234 & 100 & 0 \\
419 & 25.0 & 75.0 & 130 & 100 & 0 \\
382 & 25.0 & 75.0 & 180 & 100 & 0 \\
348 & 25.0 & 75.0 & 166 & 100 & 0 \\
372 & 37.5 & 62.5 & 172 & 100 & 0 \\
& & & 204 & 100 & 0 \\
\hline
\end{tabular}

\section{Amplification of microsatellite loci}

Genomic DNA was extracted from hair using the UltraClean ${ }^{\circledR}$ Tissue \& Cells DNA Isolation Kit following the protocol from the supplier (MoBio Laboratories, Hilden, Germany). A set of ten microsatellite loci recommended by the Food and Agriculture Organization of the United Nations (FAO) for studies of genetic diversity in cattle were selected (Table 2) (Commission on Genetic Resources for Food and Agriculture 2011; Ilie et al., 2015). Several primer modifications and amplification protocols of these loci in four multiplexes were implemented by Londoño Díaz et al. (2016) and followed in this study. Each PCR reaction contained buffer 1X, dNTP's $0.2 \mu \mathrm{M}, \mathrm{MgCl}_{2} 2.0-2.5 \mathrm{mM}$, $0.2 \mu \mathrm{M}$ of each primer, Taq polymerase $0.5 \mathrm{U}$ (Qiagen, Venlo, Netherlands) and $1 \mu \mathrm{L}$ DNA in a final volume of $15 \mu \mathrm{l}$. The amplification protocol consisted on an initial denaturation step at $94{ }^{\circ} \mathrm{C}$ for $5 \mathrm{~min}$, followed by 35 cycles of $94{ }^{\circ} \mathrm{C}$ for 30 $\mathrm{s}, 59-65^{\circ} \mathrm{C}$ for $45 \mathrm{~s}$ and $72{ }^{\circ} \mathrm{C}$ for $1 \mathrm{~min}$, and a final extension step of $72^{\circ} \mathrm{C}$ for $10 \mathrm{~min}$. PCR products were processed in an ABI Prism 3110 genetic analyzer (Applied Biosystems, Foster City, CA, USA) (Table 2). Raw data were read in Geneious v.6.1.6 (Biomatters Ltd., Auckland, New Zealand) and allele binning was done in FlexiBin (Amos et al., 2007).

Amplification and Sequencing of the Mitochondrial Control Region

Four NTC and one OTC individuals were selected based on genealogical records as representatives of all the unique mitochondrial lineages in both herds. A fragment of $379 \mathrm{bp}$ in the Mitochondrial Control Region (MCR) was amplified and sequenced with the primer pair Ilie.F (5'CAGAATTTGCACCCTAACCAA 3') and Ilie.R (5'GGGGCCTGCGTTTATATATTG 3') (Ilie et al., 2015). The PCR cocktail contained Buffer $1 \mathrm{X}$, dNTP's $0.2 \mu \mathrm{M}, \mathrm{MgCl}_{2} 2$ $\mathrm{mM}, 0.2 \mu \mathrm{M}$ of each primer, Taq polymerase 0.7 U (Qiagen, Hilden, Germany), and $1 \mu \mathrm{L}$ DNA in a final volume of $40 \mu \mathrm{L}$. The thermal profile was as follows: $94{ }^{\circ} \mathrm{C}$ for $2 \mathrm{~min}$, followed by 35 cycles at $94{ }^{\circ} \mathrm{C}$ for $30 \mathrm{~s}, 60{ }^{\circ} \mathrm{C}$ for $45 \mathrm{~s}$ and $72{ }^{\circ} \mathrm{C}$ for $50 \mathrm{~s}$, and a final step of $72^{\circ} \mathrm{C}$ for $10 \mathrm{~min}$. 
Table 2. Microsatellite markers used in this study indicating allele size, fluorochrome labeling and amplification conditions.

\begin{tabular}{|c|c|c|c|c|c|}
\hline Multipex & Locus & Size Range & Fluorochrome & $\mathrm{MgCl}_{2}$ & Temperature $\left({ }^{\circ} \mathbf{C}\right)$ \\
\hline \multirow[t]{4}{*}{1} & BM2113 & $122-138$ & FAM $^{\mathrm{TM}}$ & 2.0 & 60.0 \\
\hline & SPS115 & $246-258$ & PET $®$ & 2.0 & 60.0 \\
\hline & TGLA126 & $309-315$ & VIC® & 2.0 & 60.0 \\
\hline & ETH225 & 188-198 & FAM $^{\mathrm{TM}}$ & 2.0 & 60.0 \\
\hline \multirow[t]{2}{*}{2} & ETH10 & $214-218$ & $\mathrm{NED}^{\mathrm{TM}}$ & 2.0 & 65.0 \\
\hline & TGLA122 & $140-156$ & $\mathrm{VIC} ®$ & 2.0 & 65.0 \\
\hline \multirow[t]{2}{*}{3} & INRA32 & $166-180$ & $\mathrm{NED}^{\mathrm{TM}}$ & 2.5 & 60.0 \\
\hline & INRA64 & $220-228$ & PET® & 2.5 & 60.0 \\
\hline \multirow[t]{2}{*}{4} & BM1824 & $180-190$ & PET® & 2.5 & 59.5 \\
\hline & INRA37 & $264-288$ & $\mathrm{FAM}^{\mathrm{TM}}$ & 2.5 & 59.5 \\
\hline
\end{tabular}

A volume of $20 \mu \mathrm{L}$ of the PCR product was purified with a mix of Exonuclease I $0.5 \mathrm{U}$, Alkaline Phosphatase $0.25 \mathrm{U}$ (New England Biolabs, Ipswich, MA, USA), and milliQ water in a final volume of $30 \mu \mathrm{L}$, and incubated at $37^{\circ} \mathrm{C}$ for $30 \mathrm{~min}$. Sequencing of the clean amplicons was then outsourced with a commercial supplier. Raw sequence profiles were read and edited in Geneious v.6.1.6 (Biomatters Ltd., Auckland, New Zealand), and aligned in Mega v.7 using the ClustalW algorithm (Kumar et al., 2008).

\section{Diversity and genetic structure}

The number of alleles $(\mathrm{Na})$, effective number of alleles (Ne), observed (Ho) and expected (He) heterozygosities, probability of identity $(\mathrm{PI})$, and probabilities of exclusion (PE) for microsatellite loci were estimated in GenAlex v.6.5 (Peakall and Smouse, 2006). Corrected allele richness was estimated using rarefaction with default parameters in iNEXT (Hsieh et al., 2016). PI is defined as the probability that two randomly picked specimens in a given population share identical multilocus genotypes. PE is defined as the probability of excluding an alleged father or parent pair from parentage of a given offspring in three possible scenarios: testing one parent when the other parental genotype is unavailable (PE-1 or first parent), testing one parent when the genotype of the other parent is available (PE-2 or second parent), and when a parent pair is tested (PE-3 or parent pair) (Jamieson and Taylor, 1997; Marshall et al., 1998). The Polymorphic Information Content (PIC) was estimated with CERVUS v.3.0.7. (Marshall et al., 1998).

Testing of Hardy-Weinberg equilibrium and estimation of the Wright's fixation index (Fis) were done in Genepop v.4.6 (Rousset, 2008). Linkage disequilibrium was tested with a significance level of 0.05 and 10,000 permutations in Arlequin v.3.5.2.2 applying Holm (1979) corrections for multiple comparisons (Excoffier and Lischer, 2010). Genetic differentiation between OTC and NTC was assessed using a Principal Coordinate Analysis (PCoA) and a frequency-based Assignment test (FAT) in GenAlex v.6.5., as well as a Bayesian test of genetic differentiation in STRUCTURE v.2.3.4 (Pritchard et al., 2000; Peakall and Smouse, 2006; Garrido-Garduño and Vázquez-Domínguez, 2013). The PCoA is a multivariate method and STRUCTURE is a Bayesian approach, both designed to detect patterns of genetic differentiation within a dataset of multilocus genotypes without previous individual assignment to a candidate population. FAT is a population assignment test that estimates a log-transformed value of the probability of an individual to series of previously delimited populations based on the expected allele frequencies at each locus. The Bayesian test was implemented assuming a variable number of gene 
pools $(K)$ in the sample, from $K=1$ to $K=4$, where the most likely number was inferred estimating $\Delta \mathrm{K}$ in the Excel spreadsheet EX_TRUCTURE (González, 2018).

DnaSP v.5.10.1. (Librado and Rozas, 2009) was used to estimate nucleotide diversity, number and diversity of haplotypes and number of segregating sites in the MCR sequences. A haplotype network was constructed in PopArt (Leigh and Bryant, 2015) combining our sequences with others retrieved from GenBank for Old Type from Argentina and Britain, New Type from the USA and Argentina, and the diagnostic haplotypes for African (T1), NearEastern (T2), European (T3) and Zebuine (I1 and I2) breeds (see Accession codes in Supplementary Table 1) (Anderson et al., 1982; Troy et al., 2001; Achilli et al., 2008).

\section{Results}

\section{Genetic diversity in microsatellite loci}

The set of 10 microsatellite loci was successfully amplified in 29 individuals belonging to NTC and OTC. The total number of alleles was 44 in all loci, where SPS115 and BM2113 exhibited the largest number of alleles (five in OTC and six in NTC, respectively), whereas TGLA122 and SPS115 showed the largest effective number of alleles (3.806 and 3.982, respectively) (Table 3 ). The alleles 122 , 128 and 138 in the locus BM2113, 184 in BM1824 and 220 in INRA64 were exclusive of NTC. PI values for single loci were between 0.092 and 0.326 with a combined value of $1.89610^{-8}$ (Table 4). PE-1 was between 0.248 and 0.548 , PE-2 between 0.112 and 0.366 , and PE-3 between 0.392 and 0.739 . Combined PE-1, PE-2 and PE-3 values were $0.995,0.942$ and $>0.999$, respectively.

Table 3. Indices of genetic diversity for ten microsatellite loci in two populations of Aberdeen Angus in Colombia (Old Type Colombia and New Type Colombia).

\begin{tabular}{lccccccc}
\hline Population & Locus & $\mathbf{N}$ & Na & Ne & Ho & He & $\mathbf{F}_{\text {is }}$ \\
\hline \multirow{5}{*}{ Old Type } & BM1824 & 14 & 3 & 2.085 & 0.571 & 0.520 & -0.098 \\
& BM2113 & 14 & 4 & 3.136 & 0.857 & 0.681 & -0.258 \\
& ETH10 & 14 & 3 & 2.292 & 0.857 & 0.564 & -0.520 \\
& ETH225 & 14 & 3 & 2.513 & 0.714 & 0.602 & -0.186 \\
& INRA32 & 14 & 3 & 1.537 & 0.357 & 0.349 & -0.022 \\
& INRA37 & 14 & 4 & 2.562 & 0.857 & 0.610 & -0.406 \\
& INRA64 & 14 & 4 & 3.039 & 0.714 & 0.671 & -0.065 \\
& SPS115 & 14 & 5 & 3.596 & 0.929 & 0.722 & -0.286 \\
& TGLA122 & 14 & 4 & 3.806 & 0.929 & 0.737 & -0.260 \\
& TGLA126 & 14 & 4 & 2.741 & 0.714 & 0.635 & -0.124 \\
\hline \multirow{5}{*}{ New Type } & BM1824 & 15 & 4 & 2.018 & 0.667 & 0.504 & -0.322 \\
& BM2113 & 15 & 6 & 3.462 & 0.867 & 0.711 & -0.219 \\
& ETH10 & 15 & 3 & 1.852 & 0.467 & 0.460 & -0.014 \\
& ETH225 & 15 & 5 & 3.659 & 0.933 & 0.727 & -0.284 \\
& INRA32 & 15 & 3 & 2.103 & 0.600 & 0.524 & -0.144 \\
& INRA37 & 15 & 4 & 2.473 & 0.667 & 0.596 & -0.119 \\
& INRA64 & 15 & 5 & 3.719 & 0.600 & 0.731 & 0.179 \\
& SPS115 & 15 & 5 & 3.982 & 0.867 & 0.749 & -0.157 \\
& TGLA122 & 15 & 3 & 1.923 & 0.667 & 0.480 & -0.389 \\
& TGLA126 & 15 & 4 & 2.459 & 0.733 & 0.593 & -0.236 \\
\hline
\end{tabular}

$\mathrm{N}=$ Sample size; $\mathrm{Na}=$ Number of alleles per locus; $\mathrm{Ne}=$ Effective number of alleles; Ho $=$ Heterozygosity observed; $\mathrm{He}=$ expected Heterozygosity; $F_{\text {is }}=$ Wright's Fixation Index. 
PIC was between 0.425 and 0.723 with a mean value of 0.599. Significant deviations from HardyWeinberg equilibrium or significant inbreeding $\left(F_{\text {is }}\right)$ were not found in any locus $(\alpha \geq 0.05$, Table 3). Also, no linkage disequilibrium between any pair of loci was found after Holm's correction.

\section{Genetic structure in nuclear loci}

Genetic differentiation of NTC and OTC was evidenced in the PCoA (Figure 1), where principal components 1 and 2 provided 42.4 and $32.3 \%$ of the total genetic variation, respectively. However, an individual initially classified as OTC (AA284), was more related to NTC. The Population Assignment test in GenAlex successfully assigned every individual originally classified as OTC or NTC to its original cluster and evidenced a clear genetic differentiation of these two types (Figure 2).

Table 4. Values for Probability of Identity (PI), probabilities of Exclusion (PE-1, PE-2 and PE-3) and Polymorphic information content (PIC) for 10 loci microsatellite loci in Aberdeen Angus from Colombia.

\begin{tabular}{ccccccc}
\hline Locus & Allelic size & PI & PE-1 & PE-2 & PE-3 & PIC \\
\hline BM1824 & $180-190$ & 0.282 & 0.285 & 0.137 & 0.443 & 0.469 \\
BM2113 & $122-138$ & 0.092 & 0.548 & 0.366 & 0.739 & 0.723 \\
ETH10 & $214-218$ & 0.190 & 0.365 & 0.217 & 0.513 & 0.585 \\
ETH225 & $188-198$ & 0.158 & 0.423 & 0.257 & 0.599 & 0.624 \\
INRA32 & $176-180$ & 0.326 & 0.248 & 0.112 & 0.392 & 0.425 \\
INRA37 & $266-288$ & 0.223 & 0.339 & 0.201 & 0.496 & 0.541 \\
INRA64 & $220-228$ & 0.127 & 0.474 & 0.300 & 0.653 & 0.671 \\
SPS115 & $246-256$ & 0.110 & 0.507 & 0.330 & 0.688 & 0.699 \\
TGLA122 & $140-156$ & 0.139 & 0.451 & 0.278 & 0.628 & 0.651 \\
TGLA126 & $307-315$ & 0.173 & 0.395 & 0.239 & 0.556 & 0.606 \\
Combined & & $1.89610^{-08}$ & 0.995 & 0.942 & $>0.999$ & \\
Mean & & & & & & 0.599 \\
\hline
\end{tabular}

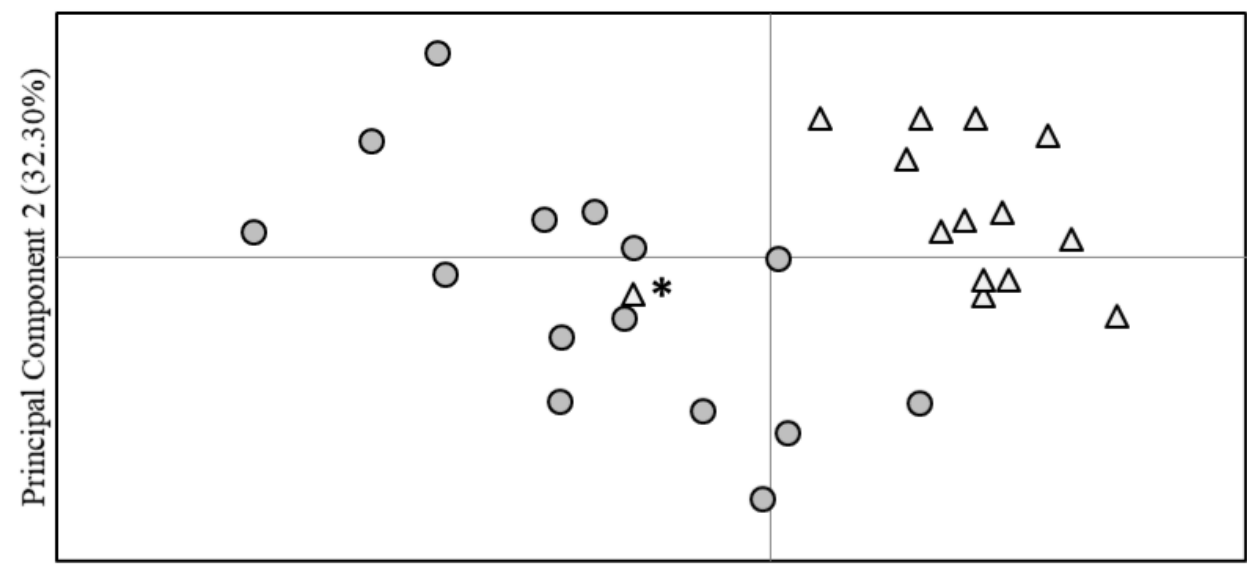

Principal Component $1(42.38 \%)$

$\Delta$ Old Type Colombia $\quad$ ONew Type Colombia

Figure 1. Principal Coordinates Analysis (PCoA) for Old Type and New Type Aberdeen Angus in Colombian herds. The asterisk points out an Old Type individual (AA284) with closer relationship to New Type. 


\section{Population Assignment}

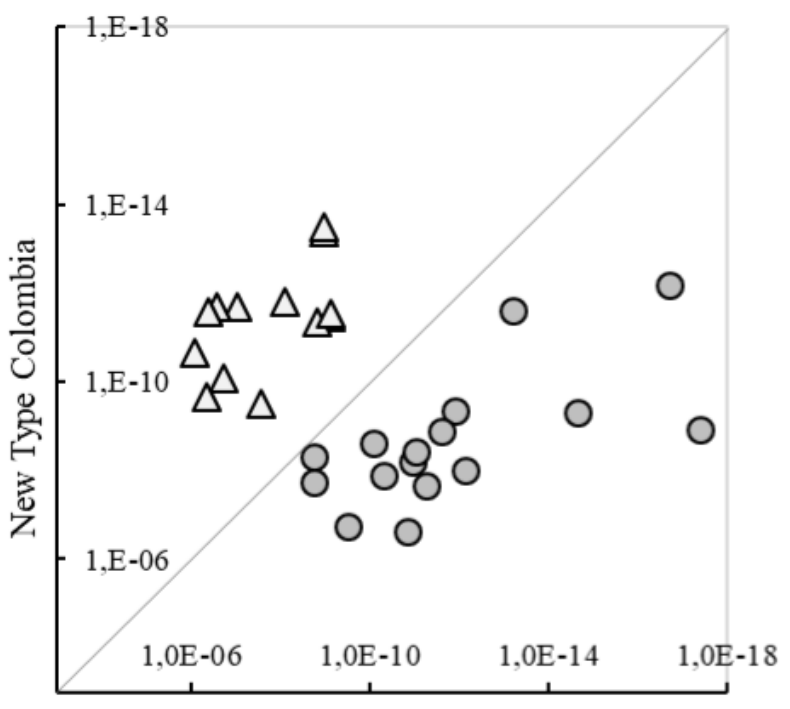

Old Type Colombia

\section{$\Delta$ Old Type Colombia ONew Type Colombia}

Figure 2. Individual probability of assignment of Aberdeen Angus in Colombian herds to their original Old and New Types.

The most likely number of gene pools in our sample, as inferred with the Bayesian population analysis in STRUCTURE, was one $(\mathrm{K}=1$; $\Delta K=8.09$ ), since substantial levels of genetic admixture were found in several individuals such as 2 (AA284), 19, 21 and 25 in Figure 3. However, the analysis with $\mathrm{K}=2(\Delta \mathrm{K}=2.04)$ allowed the recognition of two clusters that in most cases match the original classification as OTC or NTC (Figure 3).
Rarefaction curves revealed a corrected allelic richness close to an asymptotic value for all loci in both OTC and NTC, indicating only a limited effect of sampling effort on the detected levels of allelic richness (Figure 4).

Diversity and genetic structure of the Mitochondrial Control Region

The MCR sequences recovered from the five selected individuals were all different from each other (haplotype diversity of 1.0), showed 16 variable sites and nucleotide diversity of 0.00841. The haplotype network with the sequences derived from this study and those retrieved from the Genbank showed a "star" pattern around Hap_05, which is one of the European diagnostic haplotypes (T3), present in USA New Type, Argentinean New Type, British Old Type and Argentinean Old Type, but not in Colombian Aberdeen Angus sampled in this study (Figure 5). NTC was more diverse than OTC since they exhibited four and one haplotype, respectively. NTC haplotypes were Hap10, Hap25, Hap26 and Hap27; and the only haplotype present in OTC was Hap28. In particular, Hap27 is four mutational steps from both the African T1 Hap29 and Hap15 present in Argentinean New Type. Similarly, Hap26 is four mutational steps from both the European T3 Hap1 present in Argentinean New Type, and Hap18 present in British Old Type. Haplotypes Hap10 and Hap25, as well as Hap28, were between one and three mutational steps from the European Hap5 in the haplotype network.

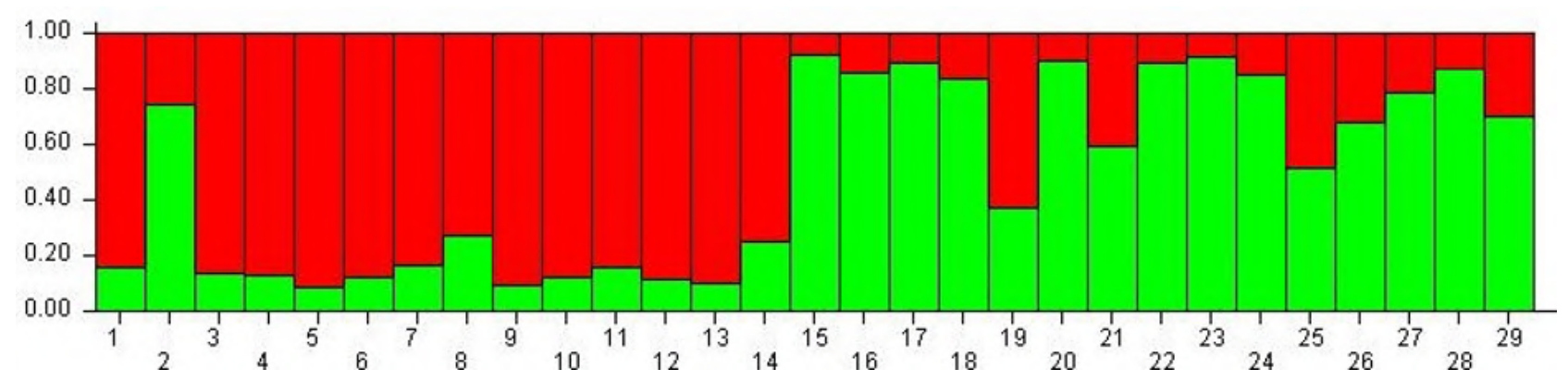

Figure 3. Assignment Test based on the Bayesian model (n=29): Old Type Colombia (1-14) and New Type Colombia (15-29). Individual AA284 corresponds to number 2 in this figure. 


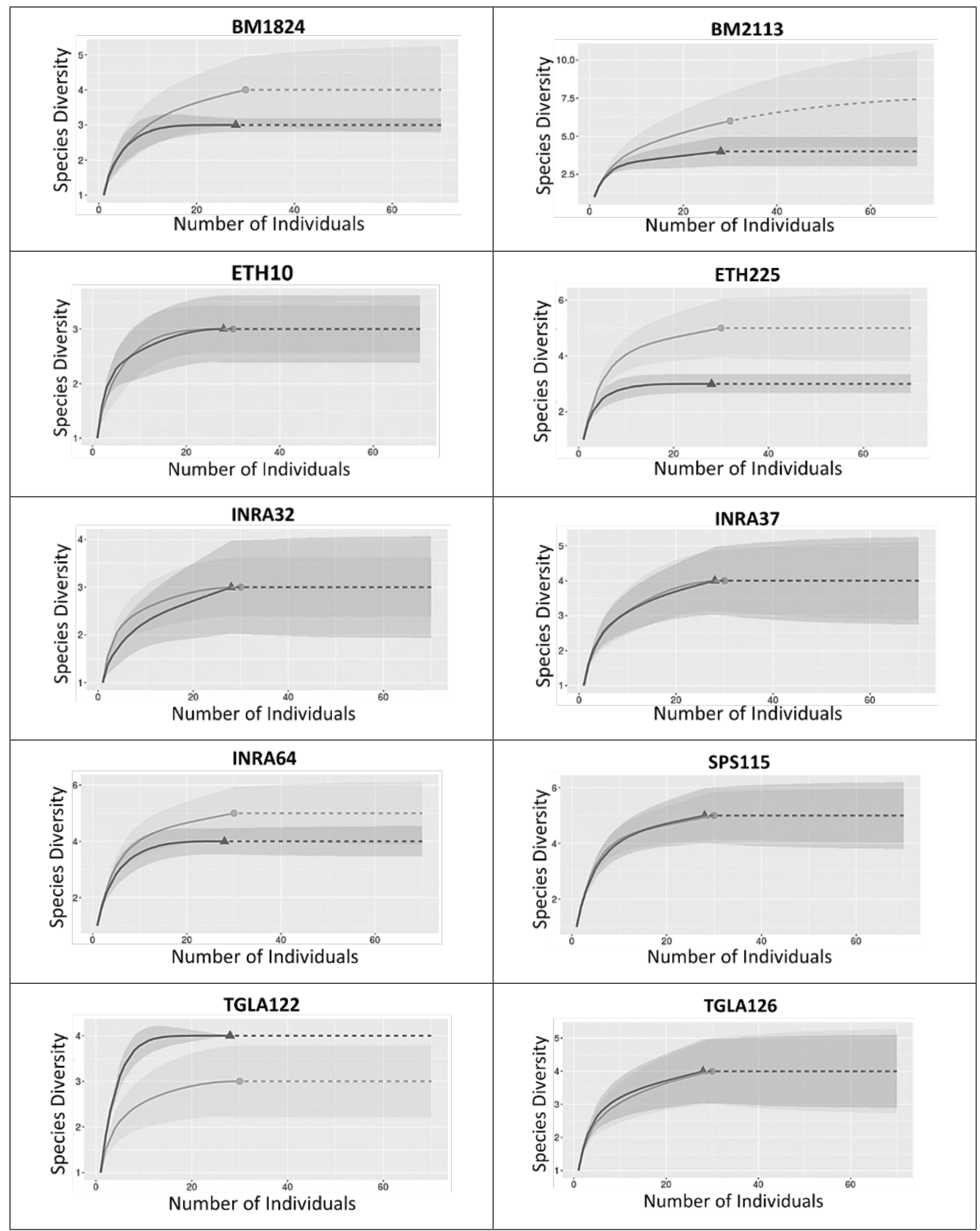

Figure 4. Curve of rarefaction for corrected allele richness of Old Type Colombia $($ OTC, $\Delta$ ) and New Type Colombia (NTC, O). Interpolated data (-) and extrapolated data (---). 


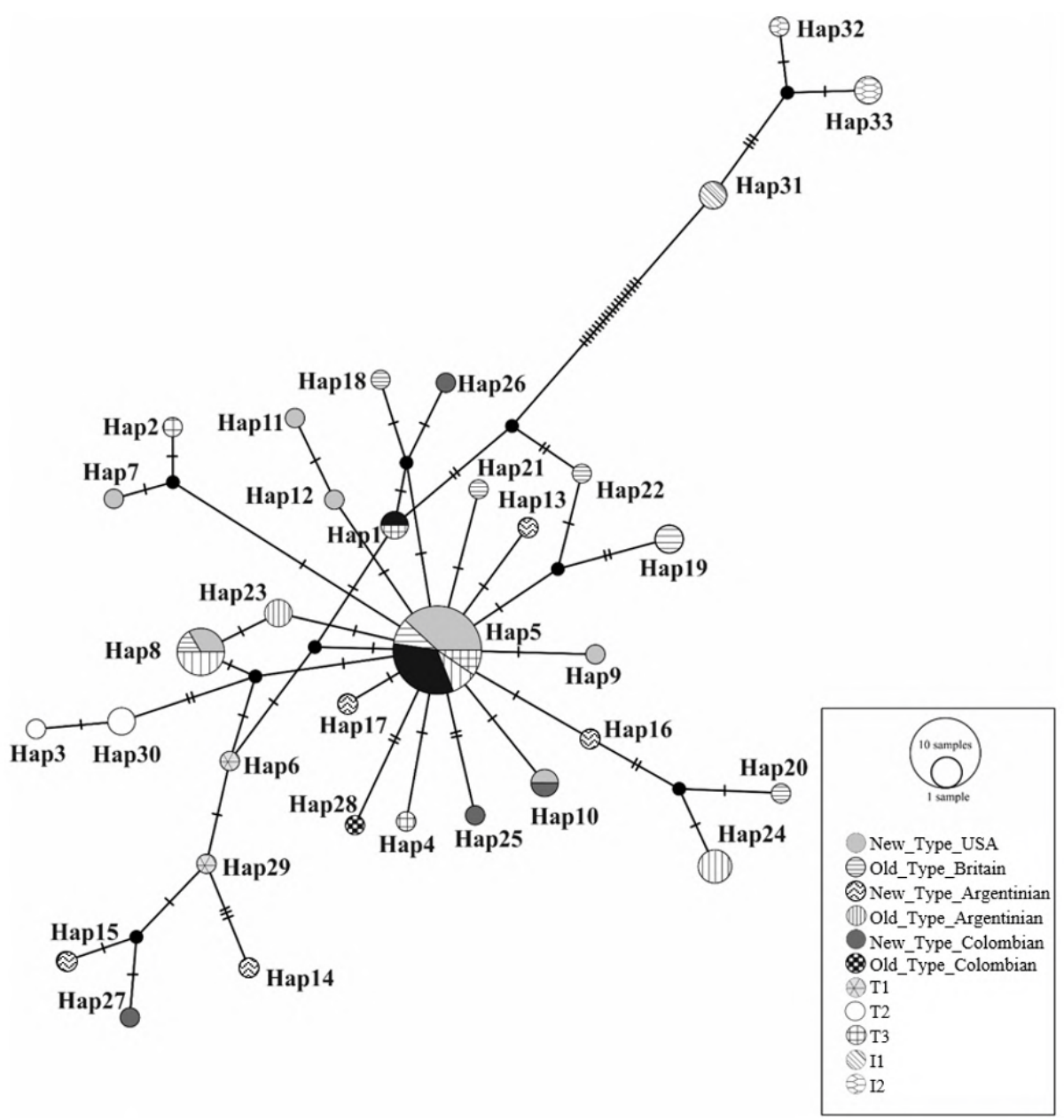

Figure 5. Haplotype network of mitochondrial sequences of Aberdeen Angus New Type USA, New Type Argentina, Old Type Britain, Old Type Argentina, New Type Colombia y Old Type Colombia. Diagnostic haplotypes for African, Near-Eastern, European and zebuine breeds are T1, T2, T3, I1 and I2, respectively.

\section{Discussion}

This study of the genetic structure and diversity of Aberdeen Angus in herds of the Colombian provinces of Cundinamarca and Huila made use of ten nucleotide markers that revealed high polymorphism and elevated levels of genetic diversity in both New Type and Old Type biotypes. These markers were very informative and good candidates for demographic studies as well as relatedness and paternity tests in Aberdeen Angus, given the high average Polymorphic Information Content (>0.5), a value of the combined Probability of Identity close to zero and Powers of Exclusion on three different scenarios that were also close to an ideal value of 0.999 (Botstein et al., 1980; Stevanovic et al., 2009; Radko, 2010; Montoya et al., 2010; Sepúlveda et al., 2012; Campos et al., 2018). However, the average number of alleles per locus was below the number previously reported for Aberdeen Angus in Antioquia, where it varied between 7 and 11 alleles for the same markers (Montoya et al., 2010). Rarefaction analysis indicated that this deficit cannot be explained by limited sampling effort and therefore may be a consequence of regional differences in population history and management.

Both analyses of population structure were consistent in the recovery of two distinct groups 
corresponding to the New Type and Old Type biotypes. The only exception to this pattern was observed in one individual, whose biotype corresponds to Old Type, but was assigned to New Type by the genetic analyses. This might be due to errors in genealogical records and incorrect morphological assignment to Old Type.

Levels of mitochondrial haplotype diversity of Aberdeen Angus in Colombia were high and similar to those previously reported for this breed in the USA, Argentina and Britain (Ginja et al., 2010). Unlike nuclear markers, genetic structure between Old Type and New Type was absent at the mitochondrial level. Several haplotypes such as Hap5 and Hap8 are present in both European and American Old Type and New Type, but a few haplotypes with restricted distribution might still be proposed as candidates to diagnose Old Type and New Type (e.g. Hap7, Hap9, Hap11 and Hap12).

All the Aberdeen Angus haplotypes found in this and other studies are clearly related to European or African Bos taurus lineages. Likewise, most NTC haplotypes correspond to European lineages, but the close relation of the NTC haplotype Hap27 to African T3 haplotypes revealed introgression in the mitochondrial genome between African and European bovines (Troy et al. 2001; Bruford et al. 2003; Ginja et al. 2010; Villegas Castagnasso et al. 2015). This pattern of mitochondrial introgression can also be observed in Argentinian New Type haplotypes (Hap15 and Hap14), given their close relationship to $\mathrm{T} 3$ haplotypes in the mitochondrial network, revealing widespread mitochondrial introgression in Latin American herds of Aberdeen Angus.

In conclusion, this study provides a set of polymorphic markers useful to trace the origins, admixture, relatedness and overall for genetic management of Aberdeen Angus in Colombia. We also proved genetic introgression in Aberdeen Angus in Colombia, mainly through crosses with females of other breeds of European or African origin.

\section{Declarations}

\section{Funding}

This study was supported by Mr. Antonio José Piñeros and Ms. Tatiana Cifuentes, owner and manageress of the "Tamalá" (Algeciras, Huila) and "Tierraleja" (La Calera, Cundinamarca) herds, respectively.

\section{Conflicts of interest}

The authors declare they have no conflicts of interest with regard to the work presented in this report.

\section{Author contributions}

AlejandraMaríaMorenoSierrawas responsible for conducting experiments, consolidating data, analyses and writing the manuscript. Mario Fernando Cerón Muñoz was responsible for conception of this study and access to biological samples. Iván Darío Soto Calderón was responsible for access to biological samples, experiment design, data analyses, project administration and edition of the manuscript.

\section{References}

Achilli A, Olivieri A, Pellecchia M, Uboldi C, Colli L, Al-Zahery N, Accetturo M, Pala M, Kashani BH, Perego UA, et al. Mitochondrial genomes of extinct aurochs survive in domestic cattle. Curr Biol 2008; 18(4): R157-R158.

Amos W, Hoffman JI, Frodsham A, Zhang L, Best S, Hill AVS. Automated binning of microsatellite alleles: problems and solutions. Mol Ecol Notes 2007; 7(1): 10-14. DOI: https://doi.org/10.1111/j.1471-8286.2006.01560.x

Anderson S, de Bruijn MHL, Coulson AR, Eperon IC, Sanger F, Young IG. Complete sequence of bovine mitochondrial DNA conserved features of the mammalian mitochondrial genome. J Mol Biol 1982; 156(4): 683-717. DOI: https://doi.org/10.1016/0022-2836(82)90137-1 
Asociación Argentina de Angus. 2014. Características Morfológicas de la Raza Angus. [accessed $2016 \mathrm{Jul}$ 6]. http://www.angus.org.ar/.

Bedoya G, Carvajal LG, Moreno FL, Davies S, Derr J, Ossa JE, Kingdom U. Estructura molecular y poblacional del ganado criollo colombiano (GCC). Rev Colomb Ciencias Pecu 2001; 14(24): 109-120. Avaible from: https://aprendeenlinea.udea.edu.co/revistas/ index.php/rccp/article/view/323757

Botstein D, White RL, Skolnick M, Davis RW. Construction of a Genetic Linkage Map in Man Using Restriction Fragment Length Polymorphisms. Am J Hum Genet 1980; 32: 314-331. PMID: 6247908; PMCID: PMC1686077.

Bruford MW, Bradley DG, Luikart G. DNA markers reveal the complexity of livestock domestication. Nat Rev Genet 2003; 4: 900-910. DOI: https://doi.org/10.1038/nrg1203

Campos J, Vargas B, Camacho J, Cruz A. Pruebas De Identidad Y Paternidad En Ganado Brahman. Agron Costarric 2018; 42(1): 49-62. DOI: https://doi.org/10.15517/rac.v42i1.32197

Commission on Genetic Resources for Food and Agriculture. 2011. Molecular genetic characterization of animal genetic resources. Rome: Commission on Genetic resources for Food and Agriculture, Food and Agriculture Organization of the United Nations. [accessed 2018 Nov 26]. http://www.fao.org/3/i2413e/i2413e00.htm

Excoffier L, Lischer HEL. Arlequin suite ver 3.5: a new series of programs to perform population genetics analyses under Linux and Windows. Mol Ecol Resour 2010; 10(3): 564-567. DOI: https://doi.org/10.1111/j.1755-0998.2010.02847.x

Garrido-Garduño T, Vázquez-Domínguez E. Métodos de análisis genéticos, espaciales y de conectividad en genética del paisaje. Rev Mex Biodivers 2013; 84(3): 1031-1054. DOI: https://doi.org/10.7550/rmb.32500
Ginja C, Penedo MCT, Melucci L, Quiroz J, Martínez López OR, Revidatti MA, Martínez-Martínez A, Delgado J V., Gama LT. Origins and genetic diversity of New World Creole cattle: Inferences from mitochondrial and $\mathrm{y}$ chromosome polymorphisms. Anim Genet 2010; 41: 128-141. DOI: https://doi.org/10.1111/j.1365-2052.2009.01976.x

González F. 2018. Web del Curso de Caracterizacion de Recursos Genéticos 2018. Software. [accessed 2018 Jun 26]. http://fernando.gonzalez.unileon.es

Holm S. A Simple Sequentially Rejective Multiple Test Procedure. Scand J Stat 1979; 6:65-70. Retrieved from http://www.jstor.org/stable/4615733

Hsieh TC, Ma KH, Chao A. iNEXT: an R package for rarefaction and extrapolation of species diversity (Hill numbers). Methods Ecol Evol 2006; 7(12): 1451-1456. DOI: https://doi.org/10.1111/2041-210X.12613

Ilie DE, Cean A, Cziszter LT, Gavojdian D, Ivan A, Kusza S. Microsatellite and Mitochondrial DNA Study of Native Eastern European Cattle Populations: The Case of the Romanian Grey. PLoS One 2015; 10(9): 1-18. DOI: https://doi.org/10.1371/journal.pone.0138736

Jamieson A, Taylor SSC. Comparisons of three probability formulae for parentage exclusion. Anim Genet 1997; 28(6): 397-400. DOI: https://doi.org/10.1111/j.1365-2052.1997.00186.x

Kumar S, Nei M, Dudley J, Tamura K. MEGA: a biologist-centric software for evolutionary analysis of DNA and protein sequences. Brief Bioinform 2008; 9(4): 299-306. DOI: https://doi.org/10.1093/bib/bbn017

Leigh J, Bryant D. Popart: full $\square$ feature software for haplotype network construction. Methods Ecol Evol 2015; 6(9): 1110-1116. DOI: https://doi.org/10.1111/2041-210X.12410 
Librado P, Rozas J. DnaSP v5: a software for comprehensive analysis of DNA polymorphism data. Bioinformatics 2009; 25(11): 1451-1452. DOI: https://doi.org/10.1093/bioinformatics/btp187

Londoño Díaz N, Cerón Muñoz MF, Soto CalderónID.Genetic diversity of Senepol cattle in Colombia using ten multiplexed microsatellites. LivestResRuralDev2016;28(8).Availablefrom: http://www.lrrd.org/lrrd28/8/lond28137.html

Marshall TC, Slate J, Kruuk LEB, Pemberton JM. Statistical confidence for likelihood-based paternity inference in natural populations. Mol Ecol 1998; 7(5): 639-655. DOI: https://doi.org/10.1046/j.1365-294x.1998.00374.x

Montoya A, Cerón M, Moreno M, Martínez E, Corrales J, Tirado J, Calvo S. Genetic characterization of the Hartón del Valle, Angus, Brangus, Holstein, and Senepol cattle breeds in Colombia, using ten microsatellite markers. Rev Colomb Ciencias Pecu 2010; 23(September): 283-291. Available from: https://aprendeenlinea.udea.edu.co/revistas/ index.php/rccp/article/view/324589

Osorio M, Toro M. 2018. Estudio de caso: Comparación morfométrica y filogenética de los biotipos de cruzamiento Aberdeen Angus de origen "escocés" y "new type" en cuatro rebaños colombianos. Universidad de Antioquia.

Peakall R, Smouse PE. genalex 6: genetic analysis in Excel. Population genetic software for teaching and research. Mol Ecol Notes 2006; 6(1): 288-295. DOI: https://doi.org/10.1111/j.1471-8286.2005.01155.x

Piñeros JA. 1980. La historia del Angus en Colombia. Obtained from Tierraleja Aberdeen Angus. Recovering on April 15, 2017. https://tierraleja.jimdo.com

Pritchard JK, Stephen M, Donnelly P. Inference of Population Structure Using Multilocus Genotype Data. Genetics 2000; 115(2):945959. PMID: 10835412; PMCID: PMC1461096
Radko A. Application of a complementary set of 10 microsatellite DNA markers for parentage verification in Polish Red cattle. Annals of Animal Science. 2010; 10:9-15. Available from: www.researchgate.net/publication $/ 287181893$ Application of a complementary set of 10 microsatellite DNA markers for parentage verification in Polish Red cattle

Rousset F. Genepop'007: a complete re-implementation of the genepop software for Windows and Linux. Mol Ecol Resour 2008; 8(1): 103-106. DOI: https://doi.org/10.1111/j.1471-8286.2007.01931.x

Sepúlveda J, Ángel P, Toro A, Corrales J, Moreno MA, Cerón-muñoz MF. Genetic variability of Senepol cattle in Colombia using molecular markers. Rev Colomb Ciencias Pecu 2012; 25: 183-190. Available from: http://www.scielo.org.co/scielo.php?script=sci arttext\&pid=S0120-06902012000200003

Stevanovic J, Stanimirovic Z, Dimitrijevic V, Stojic V, Fratric N, Lazarevic M. Microsatellite DNA polymorphism and its usefulness for pedigree verification in Simmental cattle from Serbia. Acta Vet 2009; 59: 621 - 631. DOI: https://doi.org/10.2298/AVB0906621S

Taberlet P, Valentini A, Rezaei HR, Naderi S, Pompanon F, Negrini R, Ajmone-Marsan P. Are cattle, sheep, and goats endangered species?. Mol Ecol 2008; 17(1): 275-284. DOI: https://doi.org/10.1111/j.1365-294X.2007.03475.X

Troy CS, MacHugh DE, Bailey JF, Magee DA, Loftus RT, Cunningham P, Chamberlain AT, Sykes BC, Bradley DG. Genetic evidence for Near-Eastern origins of European cattle. Nature 2001; 410: 1088-1091. DOI: https://doi.org/10.1038/35074088

Villegas Castagnasso E, Rogberg Muñoz A, Prando AJ, Baldo A, Giovambattista G. D-loop Mitochondrial genetic analysis in Abeerden Angus old type from Argentina. J Basic Appl Genet 2015; 26(2): 29-35. DOI: http://hdl.handle.net/11336/11609 